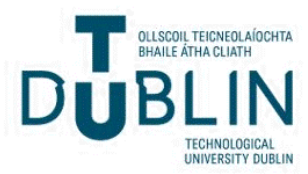

Technological University Dublin ARROW@TU Dublin

\section{Calculating restaurant failure rates using longitudinal census data}

\author{
J. J. Healy \\ Munster Technological University \\ Máirtín Mac Con lomaire \\ Technological University Dublin, mairtin.macconiomaire@tudublin.ie
}

Follow this and additional works at: https://arrow.tudublin.ie/tfschafart

Part of the Food Studies Commons, Other Arts and Humanities Commons, and the Other Food Science Commons

\section{Recommended Citation}

J. J. Healy \& Máírtín Mac Con lomaire (2019) Calculating restaurant failure rates using longitudinal census data, Journal of Culinary Science \& Technology, 17:4, 350-372, DOI: 10.1080/

15428052.2018.1459999

This Article is brought to you for free and open access by the School of Culinary Arts and Food Technology at ARROW@TU Dublin. It has been accepted for inclusion in Articles by an authorized administrator of ARROW@TU Dublin. For more information, please contact arrow.admin@tudublin.ie, aisling.coyne@tudublin.ie, gerard.connolly@tudublin.ie.

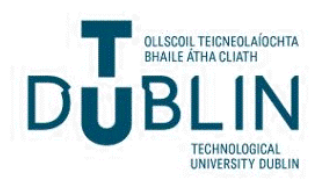




\section{Journal of Culinary Science \& Technology}

\section{Calculating restaurant failure rates using longitudinal census data}

\section{J. J. Healy \& Máírtín Mac Con lomaire}

To cite this article: J. J. Healy \& Máítín Mac Con lomaire (2019) Calculating restaurant failure rates using longitudinal census data, Journal of Culinary Science \& Technology, 17:4, 350-372, DOI: $10.1080 / 15428052.2018 .1459999$

To link to this article: https://doi.org/10.1080/15428052.2018.1459999

\section{Published online: 04 May 2018.}

\section{Submit your article to this journal $\sqsubset$}

\section{山 Article views: 803}

Q View related articles $₫$

View Crossmark data ¿

Citing articles: 5 View citing articles ๘ 


\title{
Calculating restaurant failure rates using longitudinal census data
}

\author{
J. J. Healy (10 ${ }^{a}$ and Máírtín Mac Con lomaire (1) ${ }^{b}$ \\ aDepartment of Tourism and Hospitality, Cork Institute of Technology, Cork, Ireland; bSchool of \\ Culinary Arts \& Food Technology, Dublin Institute of Technology, Dublin, Ireland
}

\begin{abstract}
Failure rates in the restaurant industry are popularly perceived to be far higher than they actually are. This paper calculates failure rates in the Irish Food and Drinks Sector (IFDS), for the first time, using longitudinal census data from the Central Statistics Office (CSO) in Ireland, which follows the European statistical classification of economic activity (NACE). The results are compared with previously published literature on restaurant failure rates in the United States of America. This study also compares IFDS failure rates with other industry sectors in Ireland (construction, manufacturing). Drawing on Stinchcombe's 'liability of newness' theory, the informal fallacies theory 'Argumentum ad Populum', and critical success factors (CSFs) for restaurants theory, the paper explores restaurant failure rates both in Ireland and internationally. The research finds that the average failure rates for the IFDS are $15 \%$ after one year; $37.62 \%$ after three years; and $53.06 \%$ after five years in business, which, although marginally higher than other industry sectors in Ireland, are considerably lower than popularly perceived. Comparisons with previous studies in the United States of America shows that Irish rates are significantly lower, particularly in the first few years. The methodology can be replicated to provide comparative studies between other European countries using the NACE classifications. The results may assist in ensuring that future policy decisions made by governments, financial institutions and other restaurant/ hospitality industry groups are more empirically based and better informed.
\end{abstract}

\section{ARTICLE HISTORY}

Received 26 November 2017 Accepted 5 March 2018

\section{KEYWORDS}

restaurants; failure-rates; Ireland; critical success factors (CSFs); food policy

\section{Introduction}

This study seeks to clarify a number of apparent misconceptions concerning restaurant failure rates, in the hope that prospective restaurateurs and entrepreneurs may be more reliably informed about the risks involved. The study calculates the failure rates of the Irish Food and Drinks Sector (IFDS), using longitudinal census data from the Central Statistics Office (CSO) in Ireland, which follows the European statistical classification of economic activity

CONTACT Máírtín Mac Con lomaire mairtin.macconiomaire@dit.ie $\Theta$ School of Culinary Arts \& Food Technology, Dublin Institute of Technology, Cathal Brugha Street, Dublin 1, Ireland

Color versions of one or more of the figures in the article can be found online at www.tandfonline.com/wcsc. 
(NACE). It also compares IFDS failure rates with other industry sectors in Ireland (construction, manufacturing). The results may help to ensure that future policy decisions made by governments, financial institutions, and other groups with an interest in the restaurant/hospitality business are more empirically based.

It is over a quarter of a century since Muller and Woods (1991) published preliminary research on the real failure rates of restaurants, which was influenced by the earlier "organizational ecology" studies of Hannan and Freeman $(1977,1984)$. They noted that "a common assumption in the restaurant industry is that restaurants fail at an exceedingly high rate," and highlighted the limited nature of "statistical research to support this assumption" (Muller \& Woods, 1991, p. 60). Despite more recent studies by other researchers on this phenomenon (see Table 1), including the seminal work of Parsa, Self, Njite, and King (2005), the common perception of high failure rates (up to 90\%) in the industry persists (Keller, 2014). This chasm between academic and popular understanding of failure rates may be explained by the numerous newspaper articles,

Table 1. Extant Literature on Restaurant Failure Rates

\begin{tabular}{|c|c|c|c|c|c|}
\hline Researchers & Year & Title & Methodology & Data source & Length \\
\hline Muller and Woods & 1991 & $\begin{array}{l}\text { The Real Failure Rate of } \\
\text { Restaurants }\end{array}$ & $\begin{array}{l}\text { Longitudinal } \\
\text { Study }\end{array}$ & $\begin{array}{l}\text { Telephone } \\
\text { Directory Data }\end{array}$ & 10 years \\
\hline $\begin{array}{l}\text { English, Josiam, } \\
\text { Upchurch \& Willems }\end{array}$ & 1996 & $\begin{array}{l}\text { Restaurant attrition: A } \\
\text { longitudinal analysis of } \\
\text { restaurant failures }\end{array}$ & $\begin{array}{l}\text { Longitudinal } \\
\text { Study }\end{array}$ & Yellow Pages & 5 years \\
\hline Parsa, Self, Njite, \& King & 2005 & Why Restaurants Fail & $\begin{array}{l}\text { Longitudinal } \\
\text { Study In- } \\
\text { depth } \\
\text { Interviews }\end{array}$ & $\begin{array}{l}\text { Dept. of Health } \\
\text { Ohio \& Interviews } \\
20 \text { owners }\end{array}$ & 3 years \\
\hline Camillo, Connolly \& Kim & 2008 & $\begin{array}{l}\text { Success and Failure in } \\
\text { Northern California: critical } \\
\text { success factors for } \\
\text { independent restaurants }\end{array}$ & $\begin{array}{l}\text { Multiple Case } \\
\text { Study }\end{array}$ & $\begin{array}{l}\text { Interview } 18 \\
\text { owners Survey } \\
\text { questionnaire } \\
\text { Participant } \\
\text { Observation }\end{array}$ & \\
\hline Parsa, Gregory \& Terry & 2010 & $\begin{array}{l}\text { Why do restaurants fail? } \\
\text { Part III: An analysis of } \\
\text { macro and micro factors }\end{array}$ & $\begin{array}{l}\text { Review of } \\
\text { Literature }\end{array}$ & & \\
\hline $\begin{array}{l}\text { Parsa, Self, Sydnor- } \\
\text { Busso, and Jin Yoon }\end{array}$ & 2011 & $\begin{array}{l}\text { Why Restaurants Fail? Part } \\
\text { II: The Impact of Affiliation, } \\
\text { Location, and Size } \\
\text { on Restaurant Failures: } \\
\text { Results from a } \\
\text { Survival Analysis }\end{array}$ & $\begin{array}{l}\text { Retrospective } \\
\text { Longitudinal } \\
\text { Data Analysis }\end{array}$ & $\begin{array}{l}\text { Dept. of health } \\
\text { data Georgia } \\
\text { Survival Analysis }\end{array}$ & 25 years \\
\hline $\begin{array}{l}\text { Parsa, van der Rest, } \\
\text { Smith, } \\
\text { Parsa and Bujisic }\end{array}$ & 2015 & $\begin{array}{l}\text { Why Restaurants Fail? Part } \\
\text { IV: } \\
\text { The Relationship between } \\
\text { Restaurant } \\
\text { Failures and Demographic } \\
\text { Factors }\end{array}$ & $\begin{array}{l}\text { Retrospective } \\
\text { Longitudinal } \\
\text { Data Analysis }\end{array}$ & $\begin{array}{l}\text { Dept. Health } \\
\text { Colorado } \\
\text { U.S. census data } \\
\text { for Colorado }\end{array}$ & 10 years \\
\hline Self, Jones and Botieff & 2015 & $\begin{array}{l}\text { Where Restaurants Fail: A } \\
\text { Longitudinal } \\
\text { Study of Micro Locations }\end{array}$ & $\begin{array}{l}\text { Retrospective } \\
\text { Longitudinal } \\
\text { Data Analysis }\end{array}$ & $\begin{array}{l}\text { Los Angles Health } \\
\text { Service Executive }\end{array}$ & 6 years \\
\hline
\end{tabular}


television programs, blogs, and websites (Beever, 2016; Feloni, 2014; Keller, 2014; O'Dell, 2010) using data that are either "incomplete, anecdotal, or superficial" (Camillo, Connolly, \& Woo Gon, 2008, p. 366). It may also be influenced by reality television programs that exaggerate the riskiness of the business overall (Dalbor, Hua, \& Andrew, 2014).

This poor perception of the restaurant industry is a major barrier for new entrants who wish to secure financial support, or for existing restaurateurs who wish to expand or grow their business, as the financial industry views investment in restaurants as high risk. This paper would hope to create a more favorable atmosphere among financial investors and governmentfunded enterprise boards by demonstrating that the failure rate in the restaurant sector is much lower than commonly perceived and that investing in the sector is not significantly more risky than investing in other businesses such as manufacturing or construction.

Most studies to date have highlighted the difficulty in obtaining accurate data (business telephone directory listings, bankruptcy reports, health department operating license permits) and how rates changed depending on what criteria were chosen, for example, if change of ownership was registered as a failure or not. Reliable statistics on small business failure are scarce and are often produced or inferred from databases designed for other purposes. As a result, and in the absence of any contrary evidence, dubious statistics suggesting very high failure rates for small enterprises are frequently quoted and have been allowed to form part of the folklore on this subject (Watson \& Everett, 1996, p. 45). Argumentum ad Populum (Latin-an argument to the people) is the logical fallacy that if a lot of people believe something, it must be true. This fallacy is not unique to small businesses or restaurants. In the field of product innovation, Castellion and Markham (2013) discuss the common assertion for new product failure rates of $80-90 \%$, despite that actual rate being around $40 \%$.

The Irish Food and Drink Sector (IFDS) is one of the largest employers in the State, a major contributor to the success of the Irish tourism industry, and a valuable financial contributor to the Irish economy (Bord Bia, 2016). The IFDS, like other sectors, can be a high-risk venture for inexperienced and uninformed entrants. However, despite the perceived high failure rates for the industry, a significant number of new businesses open every year. This paper presents the first study using longitudinal census data of failure rates in Ireland and proposes a model for similar comparative studies across Europe. This study follows a three-step process. First, through analysis of longitudinal data from the Central Statistics Office (CSO), it aims to discover original failure rates for the IFDS over a one-, three-, and five-year period. Second, these new figures for the IFDS will then be compared to international studies on failure rates in this area. This comparison of the IFDS and international restaurant failure rates was justified by using the restaurant classification 
method provided by Canziani, Almanza, Frash, McKeig, and Sullivan-Reid (2016), which demonstrated that all of the businesses outlined in the NACE descriptor (division 56) qualify to be identified as restaurants. Finally, the IFDS figures will be comparatively analyzed with failure rates in other Irish industries (construction and manufacturing).

Our findings should be of interest to researchers, financiers, advisors, and policy makers. Perhaps more importantly, our findings should also ensure that chefs, restaurateurs, or entrepreneurs who are contemplating opening a new venture are not discouraged from doing so by a false belief that new restaurant ventures are significantly less likely to succeed than other industries, such as construction or manufacturing. Our research may encourage further comparative research within an Irish and European context using the NACE classifications.

\section{Importance of food and drink sector to the Irish economy}

The IFDS was worth approximately $€ 7.5$ billion to the Irish economy in 2016 (Bord Bia, 2016). Fáilte Ireland (2014) indicated that tourists spend €2.5 billion on food and drink. In 2016, overseas visitor numbers grew by $25.9 \%$ from the 2014 level (Fáilte Ireland, 2016). Bord Bia (2016) forecast that the Irish foodservice market will have a compounded growth rate of $4.9 \%$, predicting a figure of $€ 9.1$ billion in sales for 2020. According to the CSO (2014), 108,624 people were employed full-time in the food and drink sector. The Tourism Review (Failte Ireland, 2014) report would suggest adding a further 30,000 people employed on a part-time basis. Bord Bia (2016) provide the breakdown of the Irish foodservice market, which comprises over 33,000 individual outlets, as follows:

- Limited Service 35\%

- Pubs $\mathbf{1 8 \%}$

- Hotels $\mathbf{1 7 \%}$

- Full Service 12\%

- Institutional $\mathbf{9 \%}$

- Café $5 \%$

- Other Commercial $4 \%$

The figures highlighted above demonstrate the importance of the sector to the Irish economy and the need for factual data on the failure rates for businesses in this sector. 


\section{Conceptualizing the foodservice field}

This section presents the conceptual and theoretical underpinning for restaurant failure rates. Commencing with a brief overview of historical and sociological literature globally, literature concerning restaurants in Ireland is then discussed. The paper then focuses on existing international literature on restaurant failure before addressing the critical success/failure factors (CSFs). Examples of literature on failure rates from other industries will be used to contextualize the phenomenon. Literature on restaurant segmentation will also be discussed. The paper engages with a number of theoretical discussions of factors that influence failure rates such as the "liability of newness" theory (Stinchcombe, 1965; Yang \& Aldrich, 2016); the mythology of inflated failure rates or informal fallacies "Argumentum ad Populum" (Castellion \& Markham, 2013; Engel, 1982); and finally the theories of critical success factors (CSFs) for restaurants (Camillo et al., 2008; Parsa et al., 2005).

Academic interest in restaurants and the foodservice sector has grown steadily in recent decades, starting with Mennell's (1985) treatise on eating and taste in England and France from the Middle Ages to the present using Norbert Elias' civilizing process theory, and Fine's (1996) sociological study of the culture of restaurant work. Scapp and Seitz (1998) explored the relationship between eating and culture from a variety of perspectives, including anthropology, sociology, philosophy, gender studies, race studies, and architecture. Hospitality has been explored from a societal perspective (Lashley, Lynch, \& Morrison, 2007) and from its historical origins (O'Gorman, 2010). A research focus on restaurants has been firmly established as a valid academic pursuit.

Research on failure rates and CSFs for Irish restaurants is sparse and embryonic (Bergin, 2002; Melia, 2010). Healy (2014) provides an introductory study of CSFs for Irish restaurants and profiles of two successful restaurateurs. Allen and Mac Con Iomaire $(2016,2017)$ profiled head chefs in Ireland (some of whom are Chef/proprietors) and identified success factors for Irish head chefs. However, the seminal research on restaurants in Ireland is the work of Mac Con Iomaire (2008, 2009, 2011, 2013, 2015), which is principally historic, ethnographic, and mostly focused on haute cuisine restaurants. Information booklets produced by county enterprise boards on setting up food businesses have stated that the failure rate for food businesses is $30 \%$ in the first year (Kerry County Enterprise Board, 2015). This would appear to be roughly based on some of the previously cited international studies. However, they do not reflect the real failure rate for Irish food and drink enterprises. This paper is the first to provide empirical failure rates for the Irish Food and Drink Sector. 
Various components of the European restaurant industry have received specific attention. In Sweden, Gustafsson, Öström, Johansson, and Mossberg (2006) developed a holistic Five Aspects Meal Model: a tool for developing meal services in restaurants focusing on the room, the meeting, the product, the management control system, and finally, the atmosphere. Mamalis (2009) studied critical success factors for the fast food industry in Greece; Gehrels (2013) researched success factors for small upper-segment culinary restaurant owners in the Netherlands, while Balazs (2002) explored the phenomenon of entrepreneurial threeMichelin-starred chefs in France. There remains, however, a dearth of research on restaurant failure rates in Europe.

A number of interesting studies on restaurants and foodservice have emerged from America in recent years, including research on gender in the kitchen (Harris \& Giuffre, 2015), the changing historical role and acceptance of the ethnic restaurateur (Ray, 2016), and the practice of tipping (Estreicher \& Nash, 2016). Leschziner (2015) focuses on creativity in elite restaurants but provides a comprehensive theoretical underpinning to the study of restaurants (organizational analysis, theory of action, theory of practice), particularly the notion of the culinary field, built on the cultural production theory of Bourdieu (1996) and the gastronomic field theory developed by Ferguson (1998, 2006).

The majority of the research in restaurant failure rates has been carried out in the United States. However, Hannan and Freeman (1977, p. 959) noted their frustration with the lack of empirical longitudinal studies on organizations and also highlighted that "census data are presented in a manner that renders the calculation of failure rates impossible." They further highlighted awareness that the failure rate of small businesses was high, quoting an annual failure rate estimate of upwards of $8 \%$ for small firms in the United States, partly explained by the "liability of newness" theory (Stinchcombe, 1965). New firms are believed to have high closure rates and these closures are believed to be failures, but Headd's (2003) research using two U.S. Census Bureau data sources illustrated that these assumptions may not be justified. Closure does not necessarily mean failure, as will be outlined later in this paper. Muller and Woods (1991, p. 65) proposed that other researchers, whether educators or operators, should carry out similar research in their own local markets to increase our overall understanding of real restaurant failure rates. Parsa et al. (2005) presented a model for future research suggesting that internal factors affected restaurant failures more than external factors, noting however that both internal and external factors apply. Everett and Watson (1998) found that external economic factors were associated with $30-50 \%$ of small business failures. 


\section{Restaurant failure rates}

Internationally, the principal academic studies in the field of restaurant failure have been conducted in the United States of America. Existing literature includes Muller and Woods (1991), English, Josiam, Upchurch, and Willems (1996), Parsa et al. (2005), Camillo et al. (2008), Parsa, Self, Sydnor-Busso, and Yoon (2011), Parsa, van der Rest, Smith, Parsa, and Bujisic (2015), and Self, Jones, and Botieff (2015). These studies have generated accurate percentages for success and failure in the restaurant industry in Georgia, Colorado, Texas, Ohio, and California (see Table 1). The research of Mandabach, Siddiqui, Blanch, and VanLeeuwen (2011) focused on Southern New Mexico has been omitted from Table 1, as its findings mirror those of Camillo et al. (2008).

Research by Luo and Stark (2014) that used 20 years of Bureau of Labor statistics, while interesting, is not directly relevant to this study as they concentrated on determining a failure rate for independent full service restaurants only. They found that the median lifespan of restaurants is about 4.5 years, slightly longer than that of other service businesses (4.25 years), although when measuring restaurant start-ups with 5 or fewer employees, the median lifespan is 3.75 years, slightly shorter than that of other service businesses of the same start-up size (4.0 years). As their research target is a subset of our research cohort, it cannot be considered for direct comparison. Equally, the literature on failure rates of franchises versus conventional small businesses is outside the scope of this paper (Stanworth, Purdy, Price, \& Zafiris, 1998). Mamalis (2009) identifies "adaption to locality," "place to be," and "sales incentive programs" as recent additions to the CSF family, but as his study focuses solely on the fast food industry, it could not be directly compared to this study. Muller and Woods (1994) research on restaurant segmentation has been recently updated by Canziani et al. (2016), and DiPietro (2017) highlights the gap in the literature for a more detailed breakdown of a wider range of restaurant segments when discussing failure rates and creating research projects.

When Muller and Woods (1991) conducted their 10-year study of restaurant failure, they used telephone directory listings and data from agencies that track bankruptcies to populate their data tables. A similar approach was taken by English et al. (1996) where they utilized listings in the Yellow Pages. Parsa et al. (2005) conducted their three-year project using data collected from the Columbus Health Department in Ohio. They found this to be a more accurate way to track restaurant failure.

Not only must every restaurateur renew the health permit annually, but any change in the restaurant's legal ownership requires a new permit. The health department ascribes to each restaurant location a specific identification number. This ID is a permanent number that does not change with a change in ownership. 
Similarly, each restaurant owner has a specific identification number. A comparison of the ownership and location ID numbers reveals any change in restaurant ownership. (Parsa et al., 2005, p. 309)

Muller and Woods (1991) found a failure rate of $27 \%$ in the first year, less than $50 \%$ by end of year three and $60 \%$ by end of year five. They also stated that the failure rate after 10 years was less than 70\%. In their study, English et al. (1996) found an average first-year failure rate of $26 \%, 40 \%$ in year three, and $60 \%$ in year five. Parsa et al. (2005) reported the rate of failure to be $26.16 \%$ in year one and $59.74 \%$ in year three; however, owing to their study covering the period 1996-1999, they did not record a five-year figure for failure (Figure 1).

Much of the early research data concerning failure rates for the restaurant industry focused on financial performance and considered bankruptcy reports only (Gu, 2002; Kwansa \& Cho, 1995; Urdang, 1992). Parsa et al. (2005, p. 304) noted that "most bankruptcy studies are limited in their scope, however, because many restaurant closures result from change-of-ownership actions, rather than bankruptcies." Stokes and Blackburn (2002) note a tendency to associate business "closure" with business "failure," confusing owners that close a business with "unsuccessful" entrepreneurs. This confusion is true of many small businesses. Their findings provide support for the concept of the serial entrepreneur. Everett and Watson (1998, p. 371) highlight "that a strengthening economy may provide the trigger for an increase in voluntary business exits as individual proprietors seek to maximize the returns available to them on both their financial and human capital." Headd (2003, p. 51) using two U.S. Census Bureau data sources noted:

The significant proportion of businesses that closed while successful calls into question the use of 'business closure' as a meaningful measure of business outcome. It appears that many owners may have executed a planned exit strategy,

\section{Comparison of Cumulative Average from 4 Studies}

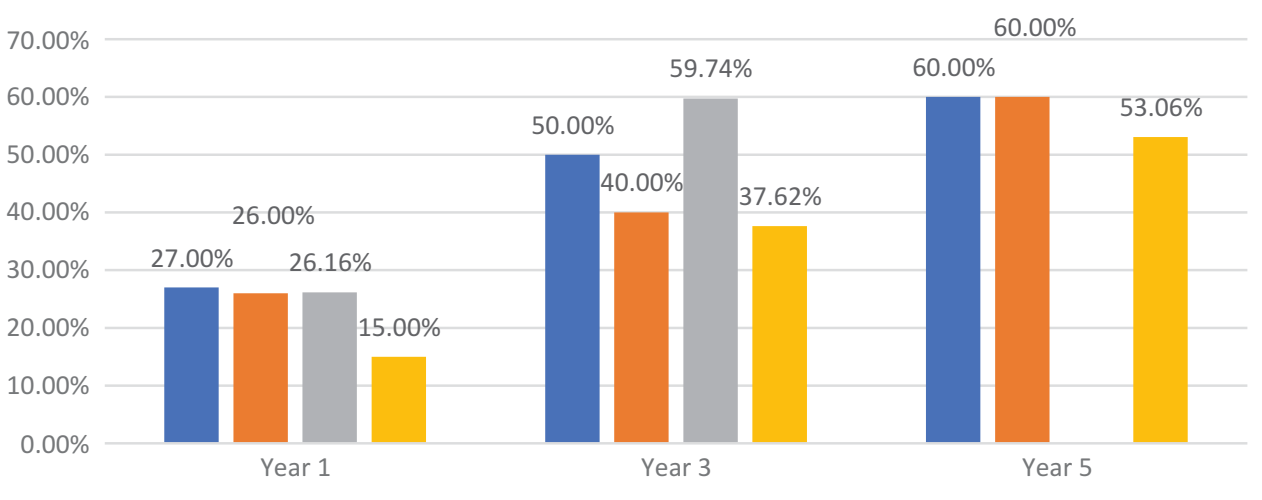

- Muller and Woods 1991 English et al 1996 Parsa et al 2005 Current Study 2017

Figure 1. Comparison of cumulative average from four studies. 
closed a business without excess debt, sold a viable business, or retired from the work force.

Mac Con Iomaire $(2009,2013)$ found that historically, many Irish restaurants closed owing to various factors such as (1) owner's ill-health, (2) lack of interest from family members to inherit the business, (3) lease/rental increases or termination by landlord, (4) suburbanization or the change of traffic flow/lack of parking. Camillo et al. (2008) highlight that weather, disease, storms, or economic downturns can also lead to restaurant failures. They conclude that bankruptcy-only studies tend to show lower failure rates than studies which incorporate broader definitions of failure (Camillo et al., 2008).

\section{Critical success factors: an overview}

Researchers have identified success and failure factors from analyses of indepth interviews with restaurateurs who experienced both sides of the business (Table 2). According to Parsa et al. (2005), there are 12 elements of success, ranging in importance from "distinctive concept" as the most important, to "location choice" as the least. Other successful elements listed were as follows:

- Long-term planning;

- Ability to adapt technology;

- On-going training for staff;

- Effective and regular communication with staff;

Table 2. List of Failure and Success Factors

\begin{tabular}{|c|c|}
\hline Common success factors & Common failure factors \\
\hline $\begin{array}{l}\text { - Concept } \\
\text { - Clear vision, act do not react, stay focused/Clear vision } \\
\text { and mission, amend strategies as situation changes } \\
\text { - Balance between family and work life/be willing to } \\
\text { make substantial time commitment to restaurant and } \\
\text { family } \\
\text { - Follow industry and technology trends/Adapt desirable } \\
\text { technologies especially for record keeping and track- } \\
\text { ing customers } \\
\text { - Competent management/Educate managers through } \\
\text { continuing education }\end{array}$ & $\begin{array}{l}\text { - Poor concept/Poor choice of location/ } \\
\text { Owner's ego } \\
\text { - Wrong pricing strategy/Negative consumer } \\
\text { perception } \\
\text { - No investment for employee training/ } \\
\text { Disrespect of staff members } \\
\text { - Lack of documented strategy/ } \\
\text { Underestimating the competition } \\
\text { - Poor management/Lack of business experi- } \\
\text { - } \quad \text { ence/frequent changes in management } \\
\text { - } \text { extequent critical incidents/Non-controllable, } \\
\text { - Lack of start-up capital or operational capital/ } \\
\text { - } \text { Eo management flexibility or innovation } \\
\text { - Entrepreneurial incompetence/Imbalance } \\
\text { between family and work life } \\
\text { - Excessive cost-cutting/lgnoring technology/ } \\
\text { Destructive emotions }\end{array}$ \\
\hline
\end{tabular}


- Maintaining clear vision, mission and strategy;

- Dividing time between business and family;

- Consistent management with a degree of flexibility;

- Poor financial management;

- Poor food quality controls;

- Quality of service;

- Finally, ill-defined concept.

Camillo et al. (2008) found that in order to succeed, operators needed to develop the following areas: (1) strategic vision, (2) business acumen, (3) competitive drive, and (4) effectively managing both front-of-house and back-of-house operations. Camillo et al. (2008, p. 378) also listed emotional factors as important success elements of a restaurateur's skills. They divided these into two categories:

- Creative-Curiosity, Love, Fondness, Confidence, Ego, Success

- Destructive-Worrying, Restlessness, Depression, Desperation, Lack of Values, Failure

Allen and Mac Con Iomaire (2016) found that personality factors also influenced the career of chefs, noting that conscientiousness, extraversion, positivity, independence, and confidence are traits that aid career success, while neuroticism and openness are barriers. American restaurateur Danny Meyer is adamant that this attention to emotional hospitality quality in his staff is one of the key factors that made him successful (Meyer, 2008). His "Virtuous Cycle of Enlightened Hospitality" philosophy underpins the success of his businesses and consists of five pillars:

- Employees;

- Guests;

- Community;

- Suppliers;

- Investors (Meyer, 2008, p. 237).

The emotional element surfaces when he speaks about the attributes he seeks when hiring staff, what he calls the " 51 percenters" (2008, p. 243). Meyer looks for $49 \%$ technical ability and excellence and for $51 \%$ emotional hospitality. They must have five core skills as part of their emotional hospitality:

- Optimistic warmth-genuine, kind, thoughtful

- Intelligence-curiosity to learn for the sake of learning

- Work ethic-to do something as well as it can be done

- Empathy-how you care for others, how your actions make others feel 
- Self-awareness and Integrity-what makes you tick, inclination to be accountable for doing the right thing with honesty and superb judgment.

Table 2, adapted from the work of Parsa et al. (2005) and Camillo et al. (2008), summarizes the common factors within the literature for both success and failure in the restaurant industry.

\section{Methodology}

The principal design employed in this paper was a retrospective longitudinal study of census data over a seven-year period (2008-2014). This method was supported by an analysis of influential literature in this area as can be seen in Table 1. The longitudinal data were obtained from the Central Statistics Office (CSO) in Cork, Ireland, based on a query submitted in January 2016. Upon contacting the CSO by email, an explanation of the Parsa et al. (2005) study was provided along with the following questions:

- How far back do your computerized records go?

- How are food businesses classified?

- How many food businesses were operating annually?

- Can they be separated by county/province/region/division/urban/rural?

- Can you identify how many new businesses open each year?

- Can you track these new operators year by year?

- When a business terminates, is there a reason recorded for this?

From this began a dialogue that ended with a table of verifiable data on enterprise births and survival numbers for businesses in the Irish Food and Drink Sector (IFDS), for a five-year period (see Table 3).

Table 3. Food and Beverage Service Activities

\begin{tabular}{lllllllll}
\hline & 2008 & 2009 & 2010 & 2011 & 2012 & 2013 & 2014 \\
\hline $\begin{array}{l}\text { Enterprise births in reference year } \\
\text { (Number) }\end{array}$ & 1044 & 989 & 1037 & 1105 & 1082 & 1014 & 1063 \\
$\begin{array}{l}\text { Enterprise births surviving one year to reference year } \\
\quad \text { (Number) }\end{array}$ &.. & 884 & 811 & 879 & 963 & 934 & 863 \\
$\begin{array}{l}\text { Enterprise births surviving two years to reference year } \\
\quad \text { (Number) }\end{array}$ &.. &.. & 762 & 709 & 776 & 842 & 819 \\
$\begin{array}{l}\text { Enterprise births surviving three years to reference year } \\
\quad \text { (Number) }\end{array}$ &.. &.. &.. & 691 & 645 & 700 & 743 \\
$\begin{array}{l}\text { Enterprise births surviving four years to reference year } \\
\quad \text { (Number) }\end{array}$ &.. &.. &.. &.. & 632 & 598 & 634 \\
$\begin{array}{l}\text { Enterprise births surviving five years to reference year } \\
\text { (Number) }\end{array}$ &.. &.. &.. &.. &.. & 590 & 554 \\
\hline
\end{tabular}

Source: Central Statistics Office (2016) 
According to the CSO and Eurostat parameters, the IFDS participants have been compiled from the NACE descriptors. NACE stems from the French "nomenclature statistique des activités économiques dans la Communauté Européenne," and is the European statistical classification of economic activities (Central Statistics Office, 2007; Eurostat, 2016). The current version was established in December 2006 by Regulation (EC) No. 1893/2006. Sector I covers Accommodation and Food Service Activities, which is further subdivided into divisions. Division 56 covers any food or beverage service activities providing complete meals or drinks fit for immediate consumption, whether served in restaurants (full service, self-service, fast food), cafés, coffee shops, delicatessen, food trucks, mobile fast food, public houses, food stalls, or event or outdoor caterers (Central Statistics Office, 2016b). The data collated from the CSO statistics has been taken from the following divisions:

- 5610-Restaurants and Mobile food service activities

- 5621-Event catering activities

- 5629-Other food service activities

- 5630-Beverage serving activities

Table 1 shows that one of the preferred methods used in the majority of studies was longitudinal data analysis, combined in some cases with in-depth interviews (Camillo et al., 2008; Parsa et al., 2005). The data collected for this current study from the CSO, similar to that of Parsa et al. (2005, p. 309), has a system of "fail-safe," in that each new food or drink enterprise in the State is provided with a unique number from the Revenue Department that is born and dies with that business. Even if the business was to change ownership and keep its original name, it would still receive a new revenue number and be classed as a new business. This has been highlighted as a potential limitation of the study. Any economic activity through revenue channels classifies the enterprise as living. If there is no economic activity for two years, the business is classed as deceased.

\section{Limitations of study}

This research was unable to access individual data for each of the divisions/ segments in the IFDS. Although the international studies looked at restaurants of all sizes and classifications and this study is examining the IFDS, the classification system devised by Canziani et al. (2016) qualifies all the establishments in division 56 as restaurants. The restaurants involved in the studies in the United States sold food and drink, and covered a broad spectrum of classification from ethnic, quick service, self-service, take-out to fine dining. They also covered independents, chains, and franchisees.

Similar to the methodology used by Parsa et al. (2005), the data for this study are collected using unique revenue numbers, which are issued when a 
business begins life. However, if the business is sold, even if the new owner continues to run the business as before and the same name is kept, a new unique revenue number is issued and it appears in the data as a new business. For example, the researchers interviewed one participant who was the third owner of a business that had been trading successfully with the same name over the door for 17 years, yet it would still have been recorded as three new businesses. Therefore, under this data set, it would register as a failure when in reality the business was still trading successfully just under new ownership. This would suggest that the real failure rate might be even lower than is currently calculated. Owing to data protection considerations, the CSO only releases data for tracking companies for a period of 5 years from birth.

\section{Findings and discussion}

The figures represented in Table 3 stem from data supplied by the CSO. The average number of new enterprises opening during the 2008-2014 period is $1,047.71$. This means that every week, approximately 20 new IFDS companies opened. The dip in premises opening in 2009 could probably be attributed to the recession and the impact of the austerity measures that were implemented by the government in 2008, but which only had knock-on effects from 2009 (O'Farrell, 2013). Similarly, the upsurge in new businesses in the years 2010, 2011, and 2012 could reflect that purchase prices and rental rates dropped dramatically during this period of the recession, thereby making it more attractive to entrepreneurs to activate new start-ups. People who had lost jobs in other industries may have used the unforeseen opportunity to move into the hospitality industry, thereby utilizing their redundancy packages to fund their new enterprises.

The failure rates were calculated by subtracting the births surviving from the previous year. Hence, if the failure rate needed to be calculated for companies that opened in 2008 (1044), this was done by subtracting the number of births surviving year one in the 2009 column (884), which would give a figure of 160. Therefore, of the 1044 businesses that opened in 2008, 160 were closed the following year. This represents a percentage failure rate of $15.33 \%$ in year one. To calculate year two failure for businesses opened in 2008, subtract births surviving two years (762) from the previous year figure (884), which means 122 companies closed in year two. This represents a $13.80 \%$ failure rate in that year. These calculations have been made for all the years and can be seen in Table 4, which shows at a glance the failure and survival rate for all new food and drink enterprises up to year five of their existence. It can be seen that the year one failure rate $(15 \%)$ is significantly lower than what is quoted in recent publications $(80 \%-60 \%-30 \%)$. It can also be seen that, as the years pass, the failure rate diminishes. On examining 


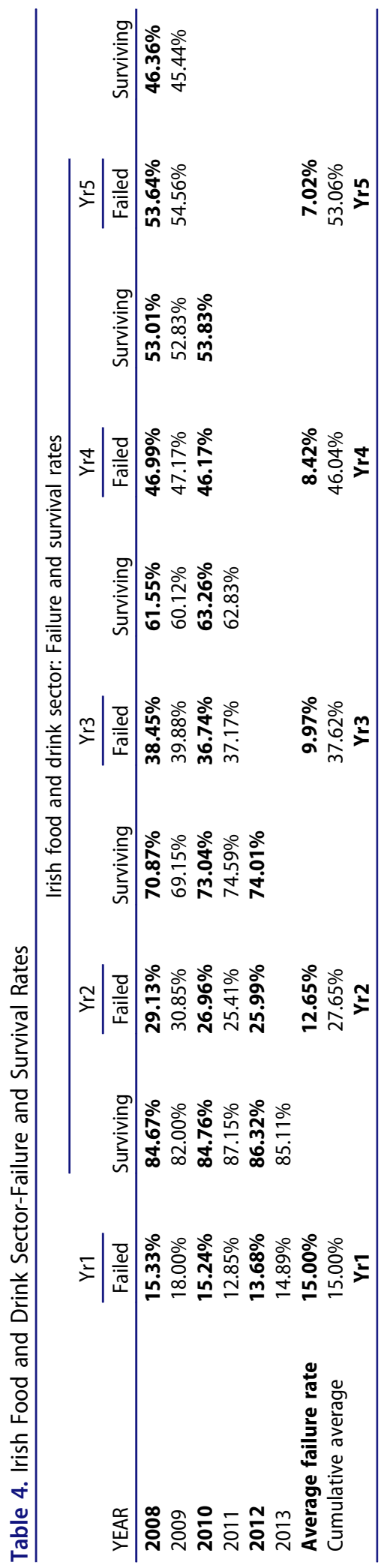


these figures, it is apparent that the IFDS failure rate is much better than popularly perceived-Argumentum ad Populum.

This decline in the failure rate year-on-year should be cause for optimism for potential start-ups and investors in the sector. The data also correspond with the international literature (Luo \& Stark, 2014; Parsa et al., 2005) that found a dramatic decline in failure rates after year five. It ties in with Stinchcombe's (1965) "liability of newness" theory where new organizations face a constellation of problems associated with their newly founded status, which renders them particularly prone to failure. Similarly, Allen and Mac Con Iomaire (2016, p. 122) found that satisfaction among head chefs in their jobs rose dramatically after year five and did not begin to fall until after the twentieth year. A factor in any new business or new position is learning the new role. A new firm must invest time, either explicitly or implicitly, in educating its new employees to execute their responsibilities. Table 4 shows the cumulative average of yearly failure rates. These are compared to the international literature in Figure 1 that clearly show a dramatic difference in year one, less difference in year three, and only a marginal difference in year five.

\section{Comparing IFDS with other sectors in Ireland}

From a similar CSO databank, we were able to extract failure rates for two other types of business sectors (manufacturing, construction), covering the same time period, and to compare these to the IFDS (see Figure 2). A

\section{Comparison of different businesses over the period 2008-2014}

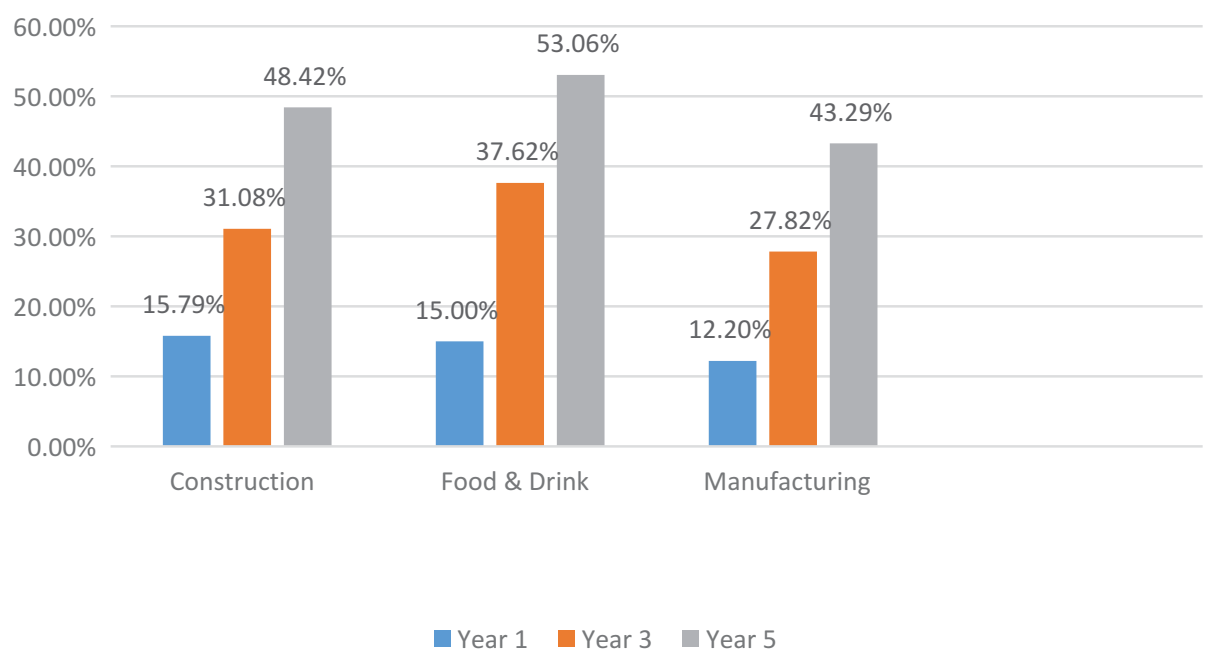

Figure 2. Comparison of failure rates with other enterprises. Source: Central Statistics Office 2016 
description of each of these sectors is available on the CSO website (Central Statistics Office, 2016a, 2016c). The comparison shows that the food and drink sector compares favorably with the other sectors. In year one, construction failure rate is higher than food and drink; manufacturing having about a $2.5 \%$ lower failure rate. In year three and year five, food and drink rates surpass construction by about $5 \%$ and are about $10 \%$ worse than manufacturing. This $5 \%$ and $10 \%$ difference, however, is still not as large a gap as popularly perceived by the public, media, and financial institutions. In addition, according to Parsa et al. (2005), restaurant failure does not have as large an impact financially on local communities as failure in other industries. Luo and Stark (2014) noted that the median lifespan for restaurant start-ups was slightly higher than that of other service businesses.

\section{Real failure rates}

It is important to note that the title of this paper "Calculating Restaurant Failure Rates using Longitudinal Census Data" differs from Muller and Woods' (1991) paper "The Real Failure Rate of Restaurants." This paper, having reviewed the international literature on small business failure (Everett \& Watson, 1998; Headd, 2003; Stokes \& Blackburn, 2002; Watson \& Everett, 1996; Yang \& Aldrich, 2016) and particularly restaurant failure rates (see Table 1), is clearly aware of how failure rates can vastly differ depending on what criteria are being applied (bankruptcy only, discontinuation of ownership, closure to prevent further losses, failure to "make a go of it," or discontinuance of business). If the "real" failure rate for restaurants was calculated based on businesses that closed down owing to lack of financial viability (Gu, 2002), the rate would be far lower than current figures indicate, even those calculated using census data. Everett and Watson (1998) highlighted that failure rates were positively associated with interest rates and the rate of unemployment, but also, somewhat unexpectedly, failure rates were found to be positively associated with lagging employment rates and with current and lagging retail sales. Headd (2003, p. 51) warned of the danger of confusing those who have executed a "planned exit strategy, closed a business without excess debt, sold a viable business, or retired from the work force" with failure; or of the "use of 'business closure' as a meaningful measure of business outcome." This is clearly an area that requires further research and clarification.

\section{Conclusions}

This study set out to clarify a number of apparent misconceptions concerning restaurant failure rates in the hope that prospective restaurateurs and entrepreneurs may be more reliably informed about the risks involved. The common fallacy Argumentum ad Populum explains the persistent myth that 
as many as 9 out of 10 restaurants fail in their first year (Keller, 2014; Lou \& Stark, 2014). Castellion and Markham (2013) highlight the role that both academics and industry bodies need to play in debunking these myths and counteracting them with accurate data in both the academic and popular press.

A number of objectives were identified at the outset of this paper: the first was to create original failure rates for the IFDS over a one-, three-, and five-year period using longitudinal census data. The second objective was to compare these Irish findings to international studies on failure rates in this area. The final objective was to compare IFDS failure rates with other Irish industries (manufacturing, construction).

This study adds to the international literature on restaurant failure rates. The paper concludes that the use of longitudinal census data can illuminate the failure rates of businesses, but identifies the difficulty of the term "real" failure rates, as these can differ depending on which criteria is applied. Hannan and Freeman (1977) lamented the manner in which census data were initially made available for research purposes. From 2008, data that enable the calculation of failure rates became available within the NACE protocol. The results for failure rates in the IFDS sector (Table 4) compare favorably with international studies (Figure 1), particularly in years one and three. When the IFDS failure rates were compared with other Irish industries (construction, manufacturing), they were higher but not dramatically so (Figure 2). The data in this study identify the real failure rate for the IFDS:

- $15 \%$ after one year in business

- $37.62 \%$ after three years in business

- $53.06 \%$ after five years in business

It must be stated that these five-year figures were calculated from businesses that started in 2008 and 2009, which was at the peak of the recession, and were still trading in their infancy during the recession. Both Fitzgerald (2014) and Whelan (2013) identified 2012 as the year in which the country began to emerge slowly from recession; nevertheless, these difficulties were also in situ for all other businesses (construction, manufacturing) during this period.

Comparison with American studies found dramatic differences in failure rates in year one and year three, but less dramatic ones, although still better (7\%), in year five. Stinchcombe (1965) argued that all new organizations suffer a "liability of newness," a greater risk of failure than older organizations, because they depend on the cooperation of strangers, have low levels of legitimacy, and are unable to compete effectively against established organizations. Yang \& Aldrich (2016) results not only confirm the "liability of newness" hypothesis, but also reveal a much higher risk of failure in organizations' early lifetime than rates found in previous research. Moreover, they highlighted the 
importance of entrepreneurs' continuing effort after their initial organizing attempts, and indicated that entrepreneurs contribute to the survival of a venture through raising more resources, enacting routines, and gaining increased public recognition of organizational boundaries. To counteract the "liability of newness phenomenon, Muller and Woods (1991, p. 64) suggested purchasing restaurants that were three years old. Within an Irish context, such an action, although potentially successful, would register on the data as a failure, which is one of the weaknesses of the CSO methodology that we have highlighted as a limitation of this research.

This paper's findings should allow first-time and existing Irish restaurateurs and entrepreneurs to approach financial institutions with more confidence of achieving access to funding for their enterprises when accompanied with an appropriate business plan. It should also allow financiers and investors to have a more open and objective perspective of the IFDS. It will allow them to recognize that this sector is not significantly more risky than investing in construction or manufacturing. The results may also help to ensure that future policy decisions made by governments, financial institutions, and other groups with an interest in the restaurant/hospitality business are more soundly based.

\section{Further research}

In the limitations of this paper we noted our inability to source segmented breakdown from the CSO. In time it may be possible to receive data from the CSO on the different divisions in the food and drink sector, thereby calculating failure rates for each division/segment and comparing results to international research such as Luo and Stark (2014) or Mamalis (2009). Muller and Woods (1994) were early researchers to highlight the importance of restaurant segmentation. Their work has been updated by Canziani et al. (2016), and DiPietro (2017) suggests that scholars developing future projects look at a wider range of restaurant segments. European segment types such as café, pub, bistro, brasserie, and pizzeria need to be adequately matched with the American quick-serve, casual dining, and family dining segmentation, so that research on both sides of the Atlantic can be equally compared. Due to data protection issues, companies are only tracked for 5 years from birth. It would provide more accurate and interesting data if this period of tracking were extended to 10 years. This would also allow research into the area of restaurant longevity. We recommend such research to be conducted as soon as segmentation data become available, and urge the CSO and their European counterparts to assist in providing such data.

Following this paper's findings about failure rates in Ireland, we recommend future research drawing on qualitative interviews with both successful restaurateurs and those who have experienced restaurant failure to examine further what factors affect failure of businesses in the IFDS. These findings 
could be compared with similar studies in other countries to see if any factors are universal, and which are culturally specific.

The data for most of this study are for the years when the Irish economy was in recession (2008-2012). It would be interesting to examine similar data from non-recession years (2014-2019) when they become available to develop a comparative analysis. Through the use of the NACE descriptors code, this study could be used as a template to investigate and compare failure rates in all the member states of the European Union. It is unclear whether the UK authorities will continue to collect data using the NACE descriptors following Brexit.

\section{ORCID}

J. J. Healy (1) http://orcid.org/0000-0001-6284-8750

Máírtín Mac Con Iomaire (D) http://orcid.org/0000-0001-6622-3299

\section{References}

Allen, H., \& Mac Con Iomaire, M. (2016). “Against all odds”: Head chefs profiled. Journal of Culinary Science \& Technology, 14(2), 107-135. doi:10.1080/15428052.2015.1080645

Allen, H., \& Mac Con Iomaire, M. (2017). Secrets of a head chef: Exploring factors influencing success in Irish kitchens. Journal of Culinary Science \& Technology, 15(3), 187-222. doi:10.1080/15428052.2016.1225538

Balazs, K. (2002). Take one entrepreneur: The recipe for success of France's great chefs. European Management Journal, 20(3), 247-259. doi:10.1016/S0263-2373(02)00040-3

Beever, S. (2016). How many new restaurants have opened in Huddersfield over the last year? The Huddersfield Daily Examiner. Rewtrieved November 27, 2016, from http://www.exam iner.co.uk/whats-on/food-drink-news/how-many-new-restaurants-opened-12114827

Bergin, B. (2002). An investigation of the key success factors and key success inhibitors in the independent Irish restaurants (Unpublished Masters Thesis). Dublin: Dublin Institute of Technology, Dublin.

Bord Bia. (2016). Irish foodservice channel insights: Growing the success of Irish food and horticulture. Dublin: Bord Bia.

Bourdieu, P. (1996). The rules of art: Genesis and structure of the literary field. Translated by: Emanuel, S. Stanford, CT: Stanford University Press.

Camillo, A. A., Connolly, D. J., \& Woo Gon, K. (2008). Success and failure in Northern California. Cornell Hospitality Quarterly, 49(4), 364-380. doi:10.1177/1938965508317712

Canziani, B. F., Almanza, B., Frash, R. E., Jr, McKeig, M. J., \& Sullivan-Reid, C. (2016). Classifying restaurants to improve usability of restaurant research. International Journal of Contemporary Hospitality Management, 28(7), 1467-1483. doi:10.1108/IJCHM-12-2014-0618

Castellion, G., \& Markham, S. K. (2013). Perspective: New product failure rates: Influence of argumentum ad populum and self-interest. Journal of Product Innovation Management, 30 (5), 976-979. doi:10.1111/j.1540-5885.2012.01009.x

Central Statistics Office. (2007). NACECoder: Central Statistics Office. Retrieved October 10, 2015, from http://www.cso.ie/px/u/NACECoder/NACEItems/searchnace.asp 
Central Statistics Office. (2014). Business demography NACE Rev 2 by activity, legal form, year and statistic - StatBank - data and statistics. Retrieved September 7, 2016, from http://www. cso.ie/px/pxeirestat/Statire/SelectVarVal/Define.asp? maintable $=$ BRA12\&PLanguage $=0$

Central Statistics Office. (2016a). Classification of Construction. Retrieved January 4, 2016, from http://ec.europa.eu/eurostat/ramon/nomenclatures/index.cfm?TargetUrl=DSP_ NOM_DTL_VIEW\&StrNom=NACE_REV2\&StrLanguageCode=EN\&IntPcKey=\&IntKey= 18507824\&StrLayoutCode=HIERARCHIC\&IntCurrentPage $=1$

Central Statistics Office. (2016b). Classification of food and beverage service activities. Retrieved January 4, 2016, from http://ec.europa.eu/eurostat/ramon/nomenclatures/index.cfm?TargetUrl= DSP_NOM_DTL_VIEW\&StrNom=NACE_REV2\&StrLanguageCode=EN\&IntPcKey= 18513674\&IntKey=18513974\&StrLayoutCode=HIERARCHIC\&IntCurrentPage=1

Central Statistics Office. (2016c). Classification of manufacturing. Retrieved January 4, 2016, from http://ec.europa.eu/eurostat/ramon/nomenclatures/index.cfm?TargetUrl=DSP_ NOM_DTL_VIEW\&StrNom=NACE_REV2\&StrLanguageCode=EN\&IntPcKey=\&IntKey= 18496334\&StrLayoutCode=HIERARCHIC\&IntCurrentPage $=1$

Dalbor, M., Hua, N., \& Andrew, W. (2014). Factors that impact unsystematic risk in the U.S. Restaurant Industry. The Journal of Hospitality Financial Management, 22(2), 89-96. doi:10.1080/10913211.2014.970047

DiPietro, R. (2017). Restaurant and foodservice research: A critical reflection behind and an optimistic look ahead. International Journal of Contemporary Hospitality Management, 29 (4), 1203-1234. doi:10.1108/IJCHM-01-2016-0046

Engel, S. M. (1982). With good reason: An introduction to informal fallacies. New York, NY: St Martins Press.

English, W., Josiam, B., Upchurch, R., \& Willems, J. (1996). Restaurant attrition: A longitudinal analysis of restaurant failures. International Journal of Contemporary Hospitality Management, 8(2), 17-20. doi:10.1108/09596119610111695

Estreicher, S., \& Nash, J. R. (2016). The case for tipping and unrestricted tip-pooling. The Social Science Research Network Electronic Paper Collection, 16(401), 1-22.

Eurostat. (2016). Statistical classification of economic activities in the European community, Rev. 2 (2008): European commission. Retrieved November 27, 2016, from http://ec.europa. eu/eurostat/ramon/nomenclatures/index.cfm?TargetUrl=DSP_NOM_DTL_ VIEW\&StrNom=NACE_REV2\&StrLanguageCode=EN\&IntPcKey=18513674\&IntKey= 18513974\&StrLayoutCode $=$ HIERARCHIC\&IntCurrentPage $=1$

Everett, J., \& Watson, J. (1998). Small business failure and external risk factors. Small Business Economics, 11(4), 371-390. doi:10.1023/A:1008065527282

Failte Ireland. (2014). Tourism-review-and-outlook-final-presentation.pdf. Retrieved May 25, 2016 http://www.failteireland.ie/FailteIreland/media/WebsiteStructure/Documents/eZine/ Tourism-Review-and-Outlook-Final-Presentation.pdf

Fáilte Ireland. (2016). Failte Ireland tourism barometer April 2016. Retrieved May 25, 2016, from http://www.failteireland.ie/FailteIreland/media/WebsiteStructure/Documents/3_ Research_Insights/3_General_SurveysReports/Failte-Ireland-tourism-barometer-April2016.pdf?ext=.pdf

Feloni, R. (2014). Food network chef robert irvine shares the top 5 reasons restaurants fail: Business insider. Retrieved October 20, 2016, from http://www.businessinsider.com/whyrestaurants-fail-so-often-2014-2

Ferguson, P. P. (1998). A cultural field in the making: Gastronomy in 19th-century France. American Journal of Sociology, 104(3), 597-641. doi:10.1086/210082

Ferguson, P. P. (2006). Accounting for taste: The triumph of French cuisine. Chicago, IL: University of Chicago Press. 
Fine, G. A. (1996). Kitchens: The culture of restaurant work. Los Angeles, CA: University of California Press.

Fitzgerald, J. (2014). Ireland's recovery from crisis. CESifo Forum, 15(2), 8-13.

Gehrels, S. A. (2013). The contextual characteristics of successful small upper segment culinary restaurant owners and their potential influence on hospitality management education. European Journal of Tourism Research, 6(2), 207-210.

$\mathrm{Gu}, \mathrm{Z}$. (2002). Analyzing bankruptcy in the restaurant industry: A multiple discriminant model. International Journal of Hospitality Management, 21(1), 25-42. doi:10.1016/S02784319(01)00013-5

Gustafsson, I. B., Öström, Å., Johansson, J., \& Mossberg, L. (2006). The five aspects meal model: A tool for developing meal services in restaurants. Journal of Foodservice, 17(2), 8493. doi:10.1111/j.1745-4506.2006.00023.x

Hannan, M. T., \& Freeman, J. (1977). The population ecology of organizations. American Journal of Sociology, 82(5), 929-964. doi:10.1086/226424

Hannan, M. T., \& Freeman, J. (1984). Structural inertia and organizational change. American Sociological Review, 49(2), 149-164. doi:10.2307/2095567

Harris, D. A., \& Giuffre, P. (2015). Taking the heat: Women chefs and gender inequality in the professional kitchen. New Brunswick, NJ: Rutgers University Press.

Headd, B. (2003). Redefining business success: Distinguishing between closure and failure. Small Business Economics, 21(1), 51-61. doi:10.1023/A:1024433630958

Healy, J. J. (2014). Craving success: An introduction to critical success factors in the restaurant industry and an overview of two successful restaurateaurs. Dublin Gastronomy Symposium, Dublin. Retrieved from http://arrow.dit.ie/dgs/

Keller, T. (2014). Why do 90 percent of restaurants fail in the first year? Retrieved March 11, 2014, from http://online.csp.edu/blog/business/why-do-90-of-restaurants-fail-in-the-firstyear

Kerry County Enterprise Board. (2015). A guide to setting up a food business. Kerry: County Enterprise Board.

Kwansa, F. A., \& Cho, M.-H. (1995). Bankruptcy cost and capital structure: The significance of indirect cost. International Journal of Hospitality Management, 14(3), 339-350. doi:10.1016/0278-4319(95)00042-9

Lashley, C., Lynch, P., \& Morrison, A. J. (Eds.). (2007). Hospitality: A social lens. Amsterdam: Elsevier.

Leschziner, V. (2015). At the chef's table: Culinary creativity in elite restaurants. Stanford, CA: Stanford University Press.

Luo, T., \& Stark, P. B. (2014). Only the bad die young: Restaurant mortality in the Western US, arXiv preprint arXiv:1410.8603. Ithaca, NY: Cornell University Library.

Mac Con Iomaire, M. (2008). Understanding the heat-mentoring: A model for nurturing culinary talent. Journal of Culinary Science \& Technology, 6(1), 43-62. doi:10.1080/ 15428050701884196

Mac Con Iomaire, M. (2009). The emergence, development, and influence of French haute cuisine on public dining in Dublin restaurants 1900-2000: An oral history (Doctoral Thesis). Dublin: Dublin Institute of Technology, Dublin. doi:10.21427/D79K7H

Mac Con Iomaire, M. (2011). The changing geography and fortunes of Dublin's haute cuisine restaurants, 1958-2008. Food, Culture \& Society, 14(4), 525-545. doi:10.2752/ $175174411 X 13088262162631$

Mac Con Iomaire, M. (2013). Public dining in Dublin: The history and evolution of gastronomy and commercial dining 1700-1900. International Journal of Contemporary Hospitality Management, 25(2), 227-246. doi:10.1108/09596111311301612 
Mac Con Iomaire, M. (2015). Haute cuisine restaurants in nineteenth and twentieth century Ireland. Proceedings of the Royal Irish Academy. Section C: Archaeology, Celtic Studies, History, Linguistics, Literature, 115, 371-403.

Mamalis, S. (2009). Critical success factors of the food service industry. Journal of International Food \& Agribusiness Marketing, 21(2-3), 191-206. doi:10.1080/ 08974430802589709

Mandabach, K. H., Siddiqui, M. A., Blanch, G. F., \& VanLeeuwen, D. M. (2011). Restaurant viability: Operations rating of contributing success factors. Journal of Culinary Science \& Technology, 9(2), 71-84. doi:10.1080/15428052.2011.580707

Melia, D. (2010). Critical success factors and performance management and measurement: A hospitality context. Retrieved November 22, 2017, from, http://arrow.dit.ie/tfschmtcon/43/

Mennell, S. (1985). All manners of food: Eating and taste in England and France from the Middle Ages to the present. Chicago, IL: University of Illinois Press.

Meyer, D. (2008). Setting the table: The transforming power of hospitality in business. New York, NY: Harper Perennial.

Muller, C., \& Woods, R. H. (1991). The real failure rate of restaurants. Hospitality Review, 9 (2), 1-8.

Muller, C. C., \& Woods, R. H. (1994). An expanded restaurant typology. Cornell Hospitality Quarterly, 35(3), 27-37. doi:10.1177/001088049403500312

O'Dell, B. (2010). The biggest mistakes restaurants make, and why they have a high failure rate. O' Dell Restaurant Consulting's Blog. Retrieved August 10, 2014, from http://blog. bodellconsulting.com/2008/03/29/the-biggest-mistakes-restaurants-make-and-why-theyhave-a-high-failure-rate/

O'Farrell, R. (2013). How did austerity affect Ireland. Dublin: Nevin Economic Research Institute. Retrieved September 10, 2016, from, http://www.nerinstitute.net/download/pdf/ ofarrell_effects_of_austerity_8th_nov_2013.pdf

O'Gorman, K. D. (2010). The origins of hospitality and tourism. Oxford, UK: Goodfellow Pub.

Parsa, H. G., Self, J., Sydnor-Busso, S., \& Yoon, H. J. (2011). Why restaurants fail? Part II The impact of affiliation, location, and size on restaurant failures: Results from a survival analysis. Journal of Foodservice Business Research, 14(4), 360-379. doi:10.1080/ 15378020.2011 .625824

Parsa, H. G., Self, J. T., Njite, D., \& King, T. (2005, August). Why restaurants fail. Cornell Hotel \& Restaurant Administration Quarterly, 46(3), 304-332. doi:10.1177/ 0010880405275598

Parsa, H. G., van der Rest, J.-P. I., Smith, S. R., Parsa, R. A., \& Bujisic, M. (2015). Why restaurants fail? Part IV: The relationship between restaurant failures and demographic factors. Cornell Hospitality Quarterly, 56(1), 80-90. doi:10.1177/1938965514551959

Ray, K. (2016). The ethnic restaurateur. London: Bloomsbury Publishing.

Scapp, R., \& Seitz, B. (1998). Eating culture. New York, NY: SUNY Press.

Self, J. T., Jones, M. F., \& Botieff, M. (2015). Where restaurants fail: A longitudinal study of micro locations. Journal of Foodservice Business Research, 18(4), 328-340. doi:10.1080/ 15378020.2015.1068670

Stanworth, J., Purdy, D., Price, S., \& Zafiris, N. (1998). Franchise versus conventional small business failure rates in the US and UK: More similarities than differences. International Small Business Journal, 16(3), 56-69. doi:10.1177/0266242698163003

Stinchcombe, A. L. (1965). Social structure and organisations. In J. G. March (Ed.), Handbook of organizations (RLE: Organizations) (pp. 142-193). London: Routledge.

Stokes, D., \& Blackburn, R. (2002). Learning the hard way: The lessons of owner-managers who have closed their businesses. Journal of Small Business and Enterprise Development, 9 (1), 17-27. doi:10.1108/14626000210419455 
Urdang, B. S. (1992). Bankruptcy and hospitality operations: Who wins? The Cornell Hotel and Restaurant Administration Quarterly, 33(1), 83-88. doi:10.1016/0010-8804(92)90057-C

Watson, J., \& Everett, J. E. (1996). Do small businesses have high failure rates? Journal of Small Business Management, 34(4), 45-62.

Whelan, K. (2013, May 24). Ireland's economic crisis: The good, the bad and the ugly. Bank of Greece Conference, Athens. Retrieved December 12, 2016, from http://www.karlwhelan. com/Papers/Whelan-IrelandPaper-June2013.pdf

Yang, T., \& Aldrich, H. E. (2016). “The liability of newness” revisited: Theoretical restatement and empirical testing in emergent organizations. Social Science Research, 63, 36-53. doi:10.1016/j.ssresearch.2016.09.006 